This is the pre-peer reviewed version of the following article: Functional brand qualities and perceived value: The mediating role of brand experience and brand personality, which has been published in final form at https://onlinelibrary.wiley.com/doi/abs/10.1002/mar.21279.

This article may be used for non-commercial purposes in accordance with Wiley Terms and Conditions for Use of Self-Archived Versions. 


\title{
FUNCTIONAL BRAND QUALITIES AND PERCEIVED VALUE: THE MEDIATING ROLE OF BRAND EXPERIENCE AND BRAND PERSONALITY
}

\begin{abstract}
Brand experience and brand personality have become two important theoretical constructs in the branding literature. However, research on the antecedents of these two constructs has been focused on intangible brand characteristics and qualities, underestimating the role of functional features. This research aims to overcome this gap by postulating that two key functional brand qualities, quality and innovativeness, help shape brand experience and personality, which, we ultimately predict, contribute to perceived value. Investments in quality and innovation have grown substantially, but how they materialize in benefits for customers and firms remains unclear. Accordingly, this study provides insights into how firms can engender the characteristics of their offer in order to build brands that are perceived by consumers as generating a valued brand experience and personality. The results from two samples provide broad support to the proposed model. Both brand quality and innovativeness contribute to brand experience and personality. Moreover, we observe that both brand experience and personality relate to perceived value. Finally, we also determined that brand personality and experience partially mediate the relationship between brand innovativeness and quality and perceived value. Hence, these results provide relevant implications for both theory and the practice of brand management.
\end{abstract}

Keywords: Brand Personality, Brand Experience, Branding, Innovativeness, Quality, Perceived Value 


\section{Introduction}

Issues related to branding have been a top management priority for some time, fueled by the realization that brands constitute "one of the most valuable intangible assets that firms have" (Keller \& Lehmann, 2006, p.740). In fact, brands have been identified as a source of numerous benefits for both firms and consumers (e.g., Ahuvia, 2005; Kotler, 2003; Keller \& Lehmann, 2006). Not surprisingly, brand management has been at the core of numerous investigations.

Differentiating a brand has become a major priority in the midst of tougher competition in the marketplace (Bao \& Sweeney, 2009). In this context, it has long been acknowledged that consumers buy products, and brands, not only for their functional characteristics but also for their symbolic content (Kim \& Sung, 2013; Sung, Choi, Ahn, \& Song, 2015). In fact, the symbolic qualities of brands have often become the main reason for consumer brand purchase (Maehle, Otnes, \& Supphellen, 2011).

Past research indicates that consumers appreciate brands that help them to enjoy life and to build and express their self-concepts (Mishra, Roy, \& Bailey, 2015; Sirgy, 1982; Sung \& Kim, 2010). Self-concept concerns the total set of an individual's thoughts and feelings with reference to himself as an object (Rosenberg, 1979). In this context, brand experience and brand personality have become two important topics in the brand management literature, which has demonstrated their determining role in the consumers' choices. Underlying the importance of these constructs is the idea that consumers appreciate brands that possess human characteristics (e.g., Eisend \& Stokburger-Sauer, 2013). Brand anthropomorphization concerns the attribution of human characteristics to brands (Puzakova, Kwak, \& Rocereto, 2013), which helps consumers in the process of expressing themselves through consumption. Therefore, brand-as-a-person is a metaphor that improves the understanding of how humans 
relate to brands, of how they develop human-related feelings like love to a brand (Carroll \& Ahuvia, 2006; Rauschnabel, Krey, Bab, \& Ivens, 2016).

Brand personality is a facet of an anthropomorphized brand (Puzakova, Kwak, \& Rocereto, 2009), and brand experience is a construct that plays a special role in helping to infuse human-like characteristics in brands, given its focus on the feelings, sensations, cognitions and behaviors produced in consumers (Brakus, Schmitt, \& Zarantonello, 2009), thus appearing as key for the development of consumer-brand relationships (Andreini, Pedeliento, Zarantonello, \& Solerio, 2018). Not surprisingly, many firms have been looking into imbuing their brands with human-like characteristics. Personalized brand characters, like Mr. Clean and the Michelin Man, as well as the utilization of spokespersons (such as Tiger Woods in the case of Accenture) help in the effort to humanize brands (Fournier \& Alvarez, 2012). As to brand experience, emotions may be evoked through colors (e.g., red in Coca-Cola) and actions stimulated by brand's slogans (e.g., "Just do it" for Nike) (Brakus et al., 2009). Relatedly, some banks, such as China Merchants and National Australia Bank, have their own fragrances (Iglesias, Markovic, \& Rialp, 2019).

In this context, understanding if investments in quality and innovation help in building brand personality and experience enlightens how firms can promote the creation of strong consumer-brand relationships. Given the contribution of brand experience and brand personality to firm performance, past research has uncovered a number of factors that help build these brand characteristics. However, past research has looked, in particular, at the role of intangible investments and qualities in shaping brand experience and brand personality, neglecting the role of functional qualities. In this vein, we contribute to existing knowledge by investigating, for the first time how two key functional brand qualities, namely quality and innovativeness, may help shape a brand's experience and personality. Innovation and quality have been at the heart of many firms' strategic movements (Molina-Castillo \& Munuera- 
Aleman, 2009). Accordingly, the investments made by firms in quality and innovation have been growing fast, in search of returns in terms of product performance (Molina-Castillo \& Munuera-Aleman, 2009). However, the positive outcomes of product quality and innovation do not always materialize (e.g., Gourville, 2006; Rust, Moorman, \& Dickson, 2002). In this context, it is of paramount importance to shed light on whether these two key functional brand aspects relate to more subjective, symbolic brand qualities. In addition, we also contribute to existing knowledge by testing whether such symbolic brand qualities contribute to perceived value. Perceived value has been linked to important psychological and behavioral responses (e.g., Cronin, Brady, \& Hult, 2000; Dodds, Monroe, \& Grewal, 1991; La, Patterson, \& Styles, 2009; Sirohi, McLaughlin, \& Wittink, 1998). Not surprisingly, it has been deemed as an important strategic objective (Cronin et al., 2000). However, previous studies have focused on outcomes of brand experience and personality with a more symbolic, relational or behavioral nature, including brand attachment, brand loyalty, and brand equity, leaving the implications of such symbolic brand qualities for perceived value unanswered. Hence, it is our proposition that functional issues may help build a brand's symbolic characteristics, which, ultimately, help shape the value proposition for consumers.

In summary, our study makes two contributions to the existing literature. Firstly, we propose that functional qualities, namely brand quality and brand innovativeness, help shape brand experience and brand personality. Secondly, we also propose that brand experience and brand personality help in carrying out the effects of brand innovativeness and quality on perceived value. We believe the pursuit of this research avenue will generate relevant insights to help managers understand how they can build brand experience and an intended brand personality (cf. Malär, Nyffenegger, Krohmer, \& Hoyer, 2012), resulting in a greater value offer to consumers. To test the research hypotheses, this investigation relies on two markedly different samples and employed structural equations modeling. 


\section{Research Background and Hypotheses}

\subsection{Consumers and Brands}

Market offers are, to a greater or lesser extent, carriers of symbolic meanings (Levy, 1959). Moreover, many buyer decisions are not based on careful decision processes, with direct evaluations of brand attributes being frequently replaced by surrogates, such as brand reputation (Olshavsky \& Granbois, 1979). To some extent, these ideas are reflected in the experiential approach to consumer decision-making, which considers that frequently the consumption process "focuses on the symbolic, hedonic, and aesthetic nature of consumption" (Holbrook \& Hirschman, 1982, p. 132). It appeals to imagery, feelings, sensations, pleasures, and other hedonic or symbolic considerations associated with individuals' buying and consumption experiences (Holbrook \& Hirschman, 1982). This approach is consistent with the view that "modern goods are recognized as essentially psychological things which are symbolic of personal attributes and goals and of social patterns and strivings" (Levy, 1959, p. 119). This approach thus brings a new orientation to the examination of the consumer-brand interaction, with brands appearing as subjective entities emanating a diverse array of symbols, and the researcher being concerned with what the brand represents, and not just what the brand is (Hirschman \& Holbrook 1982).

In this context, the idea that consumers may look at brands as relationship partners has been given a considerable amount of attention in the marketing literature (e.g., Fournier, 1998; Lam, Ahearne, Mullins, Hayati, \& Schillewaert, 2013; Sung \& Kim, 2010; Sung et al., 2015). Fournier (1998) argues that, for a brand to become a legitimate brand partner, it must be perceived as possessing human-like characteristics, that is, brands must be charged with emotion, thought, volition, and be a contributing partner of the dyad. In this context, anthropomorphized brands are "brands perceived by consumers as actual humans with 
various emotional states, mind, soul, and conscious behaviors that can act as prominent members of social ties" (Puzakova et al., 2009, p. 413-414; see also Puzakova et al., 2013). According to Maehle et al. (2011), three main reasons lead consumers to attribute human qualities to objects. Firstly, by attributing human characteristics to brands, these become more familiar. Secondly, consumers obtain comfort and reassurance when dealing with anthropomorphized brands. And thirdly, consumers reduce their uncertainty in a complex world by attributing human characteristics to brands. Hence, a strong consumer-brand relationship involves a special connection with customers, with important outcomes for firms (e.g., Aggarwal \& McGill, 2011; Chen, Wan, \& Levy, 2017; Puzakova et al., 2013). This makes it important to understand how people come to develop such relationships. In this research we look, in particular, at how firms can build two key drivers of consumer-brand relationships, namely brand personality and brand experience.

\subsection{Brand personality}

Brand personality is defined as "the set of human characteristics associated with a brand" (Aaker, 1997, p. 347). Brands come to embody human personality characteristics through consumers' learning and experience (Sung \& Kim, 2010). In this context, Aaker (1997) notes that it is apparent that Coca-Cola is cool, all-American and real; Pepsi is young, exciting and hip, and Dr. Pepper is nonconformist, unique and fun. In a prominent work, Aaker (1997) found that the concept of brand personality had five important dimensions: sincerity, excitement, competence, sophistication and ruggedness. The first three of these dimensions are similar to human personality dimensions, whereas the last two depart from the five-factor model of human personality. These findings reveal that human personality is similar, but not equal, to brand personality. This conceptualization of brand personality has since then been used in a large number of studies (see Eisend \& Stokburger-Sauer, 2013). 
Research indicates that brand personality is beneficial to companies and consumers. Specifically, firms that develop a personality for their brands evoke emotions in consumers and increase levels of trust and loyalty, thus building up consumer preference and usage (Aaker, 1997; Fournier, 1998; Rojas-Méndez, Murphy, \& Papadopoulos, 2013; Swaminathan, Stilley, \& Ahluwalia, 2008; Venable, Rose, Bush, \& Gilbert, 2005). We should not be surprised to find that "such connections play an important role in creating brand equity and maintaining long-term consumer-brand relationships" (Sung \& Kim, 2010, p. 641; see also Valette-Florence, Guizani, \& Merunka, 2011). In fact, from the consumers' point of view, brand personality can help them to create and communicate their actual or ideal personality to others in a variety of social contexts (Eisend \& Stokburger-Sauer, 2013; Huang, Mitchell, \& Rosenaum-Elliott, 2012; Lau \& Phau, 2007; Sung \& Kim, 2010).

Past research has uncovered a number of factors at the company level that help shape a brand's personality. In a meta analytic study, Eisend and Stokburger-Sauer (2013) identified advertising-related factors, including advertising complexity and consistency, hedonic benefit claims in advertising and product-related characteristics, including product design, country of origin and branding activities supporting the creation of a unique brand. Other drivers of brand personality include product type (hedonic vs. utilitarian), the use of metaphors in ads (Ang \& Lim, 2006), brand singularity, brand differentiation, and credibility of brand communication activities (Malär et al., 2012).

\subsection{Brand experience}

Because people seek sensory and intellectual stimulations and pleasure (Brakus et al., 2009; Holbrook \& Hirschman, 1982), brand experience emerged as a relevant brand characteristic or quality to be managed. Furthermore, research indicates that brand experience results in brand-related associations (Keller, 1993). Hence, some research attention has been given to 
brand experience. Notwithstanding, Andreini et al. (2018, p. 124) concluded that the development of brand experience has "only marginally affected the academic debate".

Brand experience has been conceptualized "as subjective, internal consumer responses (sensations, feelings, and cognitions), and behavioral responses evoked by brand-related stimuli that are part of a brand's design and identity, packaging, communications, and environments" (Brakus et al., 2009, p. 53). The concept of brand experience has been conceptualized as a second-order factor, comprising a sensory dimension, involving, for example, visual and tactile stimulations; an affective dimension, referring to brand-generated feelings and the emotional bond with the customer; an intellectual dimension, concerning the extent to which the brand is able to engage the customer in analytical and imaginative thinking; and a behavioral dimension, involving behavioral experiences and motor actions.

Past research indicates that delivering brand experiences results in positive consumer outcomes, including stronger brand personality associations, consumer satisfaction and brand loyalty (Brakus et al., 2009), brand equity (Lin, 2015), word-of-mouth (Klein, Falk, Esch, \& Gloukhovtsev, 2016), brand trust and brand love (Huang, 2017). Despite the importance of brand experience, studies on its antecedents are, however, quite rare. Two of the few exceptions are Klein et al. (2016), who found that a store's atmosphere, uniqueness and hedonic shopping value contribute to brand experience, while Zarantonello and Schmitt (2013) determined that event marketing also resulted in brand experience.

\subsection{Research Model and Hypotheses}

This research considers the relationship between functional (perceived quality and brand innovativeness) and symbolic qualities. Products and, more generally, brands comprise both utilitarian and symbolic attributes (Chernev, 2004; Dhar \& Wertenbroch, 2000; Keller, 2003; Lam et al., 2013). In our study, and following Hirschman and Holbrook (1982) and Holmes 
and Crocker (1987), by functional qualities we refer to the qualities of products that have a more utilitarian, tangible or rational nature, i.e., that are more closely aligned with a products' physical characteristics, and that, as such, are relatively objective features (Holbrook \& Hirschman, 1982). Some brands in the marketplace are positioned on more tangible product features, such as Duracell, which is focused on durability, whereas others lean towards more intangible brand qualities, such as Patek Philippe, a brand of watches that follows a more symbolic approach to the market with its "Begin your own tradition" theme, emphasizing the creation of a bond across generations. Functional or utilitarian qualities are emphasized in the information processing model of consumer behavior, which looks at consumers as logical/rational thinkers (Holbrook \& Hirschman, 1982). This perspective contrasts with the experiential approach to consumption, which is centered on the hedonic, symbolic, and aesthetic nature of consumption (Holbrook \& Hirschman, 1982). As Levy (1959, p. 118) put it, "people buy things not only for what they can do, but also for what they mean." Notwithstanding, it is clear that an attribute may elicit both functional and symbolic meanings.

In this context, we posit that functional qualities contribute to shape more intangible, symbolic brand characteristics, namely brand experience and brand personality, which in turn drive consumers' value perceptions. Specifically, we predict that two key functional qualities that have been at the core of strategic initiatives for many companies, namely brand quality and innovativeness (Molina-Castillo \& Munuera-Aleman, 2009), are key for building brand experience and brand personality. Perceived brand quality refers to consumers' perceptions regarding the degree of excellence of a brand (Zeithaml, 1988), whereas brand innovativeness is defined as “consumer's perception of an enduring firm capability that results in novel, creative, and impactful ideas and solutions for the market" (Kunz, Schmitt, \& Meyer, 2011, p. 817). As Brakus et al. (2009, p. 63) put it, "both brand experiences and judgements of a 
brand's personality occur in response to brand contact", and this should encompass contact with brand characteristics, including quality and innovativeness. The latter two are primary associations that generate benefits for consumers (see Netemeyer et al., 2004), and brand experience and personality are symbolic attributes that frequently result from primary associations (e.g., Malär et al., 2012). Finally, our model further tests whether brand personality and experience contribute to perceived value, and whether they help in carrying out the effects of brand quality and innovativeness on perceived value, which has been defined as the overall assessment made by customers involving a comparison between "perceptions of what is received ... and what is given" (Netemeyer et al., 2004, p. 211). Our research model is depicted in Figure 1 (please see Table 1 for a summary of all constructs' definitions).

$* * * * * * * * * * * * * * * * * * * * * * * * * * * * *$

Insert Figure 1 about here

$* * * * * * * * * * * * * * * * * * * * * * * * * * * * *$

$* * * * * * * * * * * * * * * * * * * * * * * * * * * * *$

Insert Table 1 about here

$* * * * * * * * * * * * * * * * * * * * * * * * * * * * *$

\section{The Outcomes of Brand Innovativeness}

Brand innovativeness refers to the degree to which consumers perceive the brand as creative and as challenging the market with new ideas and solutions (Kunz et al., 2011). Creativity and innovation are widely acknowledged as key requirements for organizations wishing to retain their competitiveness and, consequently, their performance in environments marked by 
rapidly changing competition, technologies, and markets (e.g., Gilson, Mathieu, Shalley, \& Rudy, 2005; Han, Kim, \& Srivastava, 1998). Innovativeness should have an impact on brand experience and personality. Consumers' judgements about a brand's personality draw on contacts with brand elements, including product-related attributes (Aaker, 1997). Brands can be perceived as innovative if they systematically offer creative solutions, which may include aspects such as a new product design, new product attributes, new marketing approaches and unique offers in the market (Kunz et al., 2011; Moorman, 1995). Hence, innovation makes consumers feel that brands with such characteristics are at the forefront of developing offerings that respond to customer needs in an original way, helping in communicating the uniqueness (Fang, 2008) and superiority of a brand to consumers (Calantone, Chan, \& Cui, 2006), and this may originate perceptions that a brand is, for example, sophisticated. Moreover, brand innovation may include new colors, materials, forms, and textures, affecting consumers' senses (Long, 2002). Additionally, innovativeness can take the form of heightened functionality. Hence, innovativeness may lead to customer surprise and an enhanced consumption experience (Menguc, Auh, \& Yannopoulos, 2014; Veryzer \& Mozota, 2005), resulting in consumer enthusiasm. Not surprisingly, Molina-Castillo and MunueraAleman (2009) argue that innovative offers may evoke positive feelings in customers' minds. This is in line with previous research showing that innovation positively affects consumers (Han et al., 1998). Moreover, innovativeness should result in higher perceptions of product quality. Perceived quality concerns the extent to which consumers perceive as excellent a specific brand (Zeithaml, 1988). Innovativeness involves the offer of unique attributes (Calantone et al., 2006) as well as of improved attributes. Given that consumers form perceptions of product quality from functional and non-functional attributes (Dodds et al., 1991), innovation, i.e., improvements at such levels should lead consumers to perceive an increased brand ability to address customers' needs, and this should result in enhanced 
perceptions of brand excellence, i.e., brand quality. Finally, as innovativeness provides added benefits for consumers, it should also result in an increase in perceived value (Moultrie, Clarkson, \& Probert, 2007). By enhancing product aesthetics, functionality and compatibility, by inserting novel product capabilities, and by enhancing current or adding novel service attributes, innovation brings improvements on how consumers use and feel about the product, thus providing added value (Veryzer \& Mozota, 2005). Hence, we offer the following:

H1: Brand innovativeness is positively related to perceived brand quality

H2: Brand innovativeness is positively related to brand experience

H3: Brand innovativeness is positively related to brand personality

H4: Brand innovativeness is positively related to perceived value

\section{The Outcomes of Perceived Quality}

Perceived quality refers to the perception of the degree of excellence of a certain brand (Zeithaml, 1988) compared to other brands (Netemeyer et al., 2004). It has been stated that "quality is perhaps the most important and complex component of business strategy. Firms compete on quality, customers search for quality, and markets are transformed by quality" (Golder, Mitra, \& Moorman, 2012, p. 1). Being considered one of the best brands available in the market is a key reason for consumers to develop a brand love relationship (Batra, Ahuvia, \& Bagozzi, 2012). This signals that quality, i.e., exceptional performance, should exert a strong impact on how consumers experience a brand. A higher quality means an experience that is free from deficiencies and that better addresses customers' needs (Fornell, Johnson, Anderson, Cha, \& Bryant, 1996). Moreover, perceptions of an exceptional quality and of the fulfilment of customers' expectations suggest that the brand goes to great lengths in order to serve customers, and this is likely to drive consumers to perceive the brand as competent and sophisticated, for example. In addition, customers' perceptions that a brand fulfilled its 
expectations, which a company can achieve by listening to its customers, for example, crafting an adequate production and quality control process and crafting a good attribute design process (Golder et al., 2012), should lead customers to perceive the brand as caring for its customers. Hence, brand quality is likely to influence the customers' assessment of brand experience and brand personality. Not surprisingly, many studies have determined that quality is a relevant antecedent of customer satisfaction (e.g. Lam et al., 2013). Finally, perceived quality should also contribute to perceived value, which is a more abstract construction that considers both the benefits and costs of an offer, thus including quality evaluations. As Aaker (1996) argued, perceived quality is associated with several functional benefit variables. Hence, we propose the following:

H5: Perceived quality is positively related to brand experience

H6: Perceived quality is positively related to brand personality

H7: Perceived quality is positively related to perceived value

\section{The Outcomes of Brand Experience}

Aaker (1997) acknowledges that consumers' brand personality perceptions are influenced by any direct and indirect contacts they have with a brand, such as brand users and endorsers, company representatives, product-related attributes, brand name and advertising. In this context, any consumer experiences associated with a brand are likely to be used in the inferential process used by consumers to build their perceptions of a brand's personality (Brakus et al., 2009). A distinct brand personality is built through the personification of brand attributes (Schembri, 2009). Hence, by infusing brands, inanimate objects, with attributes that lead consumers to experience a brand as emotional or intellectual, firms contribute to the formation of brand personality (cf. Brakus et al., 2009). Moreover, brand experience should 
contribute to perceived value as consumers also appreciate the sensations, feelings, and pleasures of consumption (Holbrook \& Hirschman, 1982). Hence, we offer the following:

H8: Brand experience is positively related to brand personality

H9: Brand experience is positively related to perceived value

\section{The Outcome of Brand Personality}

Perceived value refers to an overall assessment that consumers make after weighing what they get from a brand and what they give (Zeithaml, 1988). Given that brand personality generates trust and helps consumers create and communicate a specific personality to others (e.g., Eisend \& Stokburger-Sauer, 2013), it creates benefits for customers and, as such, it should contribute to perceived value. Therefore, we predict the following:

H10: Brand personality is positively related to perceived value

\section{Method}

\subsection{Data Collection}

To test our research hypotheses, and similarly to other studies (e.g., Zanjani, Milne, \& Miller, 2016), we rely on two markedly different samples, varying in age, income and cultural background, which provides insights into the generalizability of the predictions in our model. By doing so we address calls for replication in scientific investigation in management (e.g., Evanschitzky \& Armstrong, 2013; Uncles \& Kwok, 2013). The first sample is composed of students from a major university in the center of Portugal. We distributed 2,000 questionnaires to students across the campus and placed closed ballot boxes across it to collect the questionnaires and ensure students of the anonymity of their responses. After eliminating questionnaires with excessive missing responses, we retained 534 for analysis, a 
net response rate of $26.7 \%$. As to the respondents, $51.1 \%$ are male, the average age is 24 years, and $82.3 \%$ are full-time students. The second sample is composed of Americans who were recruited through MTURK. In order to ensure data quality, respondents were required to have at least 100 hits completed and a success rate of $95 \%$. In line with other studies, we inserted a question to filter out those filling out the questionnaire carelessly (cf. Peer, Vosgerau, \& Acquisti, 2014). After eliminating the questionnaires whose respondents failed to disagree with the statement "I am not really reading the questions of this survey" (inserted alongside other constructs' items), we retained 282 for analysis. As to the respondents, $42.2 \%$ were men, the average age being 39 years.

\subsection{Measurement}

In the first (student) sample, and in line with previous studies on branding (e.g., Alexandrov, Lilly, \& Babakus, 2013; Choi \& Winterich, 2013; Tuskej, Golob, \& Podnar, 2013), respondents were asked to write the name of a brand that they have been using and with which they believed to have a special and strong relationship. With this approach, which is common in the literature, respondents freely indicated the brand. This contributes to the generalization of results. However, as the type of product may have an influence over the drivers of brand personality and brand experience, in the second (Mturk) sample, respondents were instructed to think of the cellphone brand that they currently used (or the one that they used the most). Subsequently, respondents were requested to provide information regarding the measures of interest.

The pretested questionnaire relied on previously validated measures and used a seven-point Likert scale. Brand innovativeness is from Fang (2008), perceived quality is from Lam et al., (2013), brand experience is from Brakus et al. (2009), brand personality is from Aaker 
(1997) and perceived value is from Netemeyer et al. (2004). All measures were subjected to confirmatory factor analysis (table 2).

$* * * * * * * * * * * * * * * * * * * * * * * * * * * * *$

Insert Table 2 about here

$* * * * * * * * * * * * * * * * * * * * * * * * * * * * *$

After model purification, we obtained an acceptable fit (sample 1: $\chi 2=1768.89$, df $=610$; $\mathrm{IFI}=0.91 ; \mathrm{TLI}=0.90 ; \mathrm{CFI}=0.91 ; \mathrm{RMSEA}=0.06 ; \chi^{2} / \mathrm{df}=2.90 ;$ sample $2: \chi^{2}=1712.69, \mathrm{df}=647$; $\mathrm{IFI}=0.91 ; \quad \mathrm{TLI}=0.90 ; \mathrm{CFI}=0.90 ; \mathrm{RMSEA}=0.08 ; \chi 2 / \mathrm{df}=2.65)$. We obtained evidence of convergent validity as all items loaded on the appropriate factors, with the loadings being significant. Furthermore, in all cases, the composite reliability exceeds the recommended 0.70 threshold level. As to the average variance extracted, all values exceed the 0.60 mark. Moreover, we obtained evidence of discriminant validity when we compared the squared correlations with the average variances extracted (Fornell \& Larcker, 1981). Hence, the measurement models show acceptable levels of reliability and validity. Table 3 provides univariate statistics, correlation coefficients, Cronbach alphas, average variances extracted, and composite reliabilities for both samples.

$* * * * * * * * * * * * * * * * * * * * * * * * * * * * *$

Insert Table 3 about here

In order to minimize common method variance (CMV), the questionnaire was designed considering some fundamental aspects (Podsakoff, Mackenzie, Lee, \& Podsakoff, 2003). 
First, the respondents were not informed about the main topic of this investigation. Secondly, respondents were assured that their answers would be anonymous and confidential. Finally, we informed respondents that there were no right or wrong answers and we stressed that their participation was very important for this investigation. We also relied on established scales in order to minimize the possibility of ambiguous items or complex words. Additionally, we ran a number of statistical procedures to assess whether method variance was affecting the estimations. Initially, we conducted the Harman one-factor test and determined that the first factor accounted for less than $50 \%$ of the variance in both samples. We also ran a confirmatory factor analysis with a single factor and determined that model fit was unacceptable in both cases. Following Lindell and Whitney (2001), we included in the questionnaires a three-item marker variable - the extent to which consumers find it easy to shop on the internet (Childers, Carr, Peck, \& Carson, 2001). Accordingly, we adjusted the correlations between each independent variable and the dependent variables using the lowest correlation between the marker variable and the variables of interest (Lindell \& Whitney, 2001). All the adjusted correlations remained significant, which suggest that CMV is not a major issue in this investigation.

As we relied on samples from different cultural contexts, we tested for measurement invariance. Given that we are essentially concerned with the relationships between constructs in a nomological network, only configural and metric invariance are required (Steenkamp \& Baumgartner, 1998). In conducting the CFA described above, given the caveats associated with the introduction of correlated measurement residuals (Bagozzi, 1983; Fornell, 1983; Gerbing \& Anderson, 1984), we eliminated a few items for each sample in order to obtain an adequate fit. However, to test whether the meaning attached to the items across cultures was invariant, and following the practices described in the measurement invariance literature (Byrne, 2008; Byrne, Shavelson, \& Muthén, 1989; Little, 1997), we introduced error 
covariances to improve model fit. Hence, initially we ran separate CFAs for sample 1 and sample 2, introducing a few error covariances for each sample to obtain an acceptable fit (fit

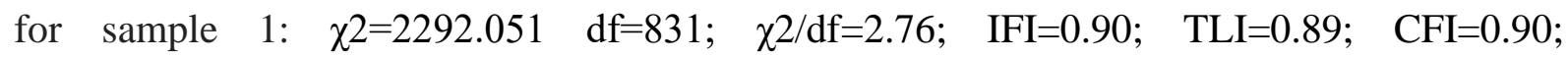
RMSEA=0.06; fit for sample $2: \chi 2=2040.519, \mathrm{df}=835 ; \chi 2 / \mathrm{df}=2.44 ; \mathrm{IFI}=0.90, \mathrm{TLI}=0.89$, $\mathrm{CFI}=0.90, \mathrm{RMSEA}=0.07)$. After establishing these baseline models, we ran a non-constrained multigroup CFA, which denoted a similar fit to the baseline models $(\chi 2=4452.5, \mathrm{df}=1666$; $\chi 2 / \mathrm{df}=2.67 ; \mathrm{IFI}=0.90 ; \mathrm{TLI}=0.89 ; \mathrm{CFI}=0.90 ; \mathrm{RMSEA}=0.05)$, indicating configural invariance. Subsequently, we ran an additional multigroup CFA with factor loadings constrained to be

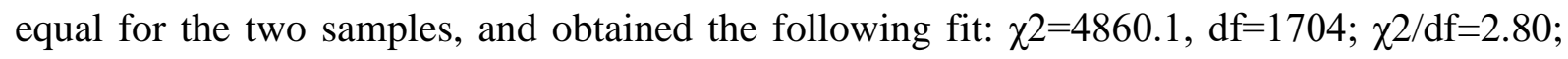
$\mathrm{IFI}=0.89 ; \mathrm{TLI}=0.88 ; \mathrm{CFI}=0.89 ; \mathrm{RMSEA}=0.05)$. A $\chi^{2}$ difference test has frequently been used in order to compare models, i.e., to test the equality of restrictions and, thus, to conclude about equivalence. However, researchers have argued against this criterion (e.g., Byrne, 2008; Little, 1997; Cheung \& Rensvold, 2002), stating that the " $\Delta \chi 2$ value is an impractical and unrealistic criterion upon which to base evidence of equivalence” (Byrne, 2008, p. 878), with the difference in CFI $(\triangle \mathrm{CFI})$ being increasingly considered for comparison purposes (Byrne, 2008). Following Cheung and Rensvold (2002), a CFI difference below 0.01 is indicative of equivalence, and we obtained this $(\triangle \mathrm{CFI}=0.009)$, demonstrating metric invariance.

\section{Results}

We tested the research hypotheses relying on AMOS (version 25). The fit of the structural model is within established standards (sample 1: $\chi 2=1768.89, \mathrm{df}=610 ; \mathrm{IFI}=0.91 ; \mathrm{TLI}=0.90$; $\mathrm{CFI}=0.91 ; \quad \mathrm{RMSEA}=0.06 ; \quad \chi^{2} / \mathrm{df}=2.90 \quad$ and sample $2: \quad \chi^{2}=1712.69, \quad \mathrm{df}=647 ; \quad \mathrm{IFI}=0.91 ;$ $\mathrm{TLI}=0.90 ; \mathrm{CFI}=0.90 ; \mathrm{RMSEA}=0.08 ; \chi 2 / \mathrm{df}=2.65)$. Apart from the predicted model (Model 1$)$, we also tested a number of alternative models (see Table 4): Model 2, which considers only 
the direct effects of functional and symbolic qualities on perceived value; Model 3, which investigates the effects of the functional qualities on perceived value; Model 4, which considers the sole effects of the symbolic qualities on perceived value; Model 5, which contains the effects of the functional qualities on brand experience; and Model 6, which explores the effects of functional qualities on brand personality. These alternative models enable the assessment of the explanatory power of the different independent variables. The hypothesized model (Model 1) provides a superior explanatory power over perceived value compared to Models 3 and 4, and an explanatory power similar to Model 2, but adding insights into how quality and innovativeness contribute to symbolic qualities. The discussion of results will focus on the hypothesized model (Model 1).

Subsequently, we present the results of hypotheses testing. As predicted, brand innovativeness is positively related to perceived quality, supporting $\mathrm{H} 1$ (b1=0.565, $\mathrm{p}<0.01 ; \mathrm{b} 2=0.822$, $\mathrm{p}<0.01)$. Brand innovativeness is positively related to brand experience and brand personality, thus supporting $\mathrm{H} 2(\mathrm{~b} 1=0.385, \mathrm{p}<0.01 ; \mathrm{b} 2=0.419, \mathrm{p}<0.01)$ and $\mathrm{H} 3(\mathrm{~b} 1=0.282, \mathrm{p}<0.01$; $\mathrm{b} 2=0.415, \mathrm{p}<0.01)$. Contrary to what we expected to find, brand innovativeness did not relate to perceived value (H4) in sample 1, and in sample 2 the sign was opposite to what was predicted $(\mathrm{b} 1=-0.025, \mathrm{p}>0.05 ; \mathrm{b} 2=-0.423, \mathrm{p}<0.01)$. However, we note that in Model 3, which explores the sole effect of functional qualities on perceived value, the relationship between innovativeness and perceived value emerges with a positive and significant coefficient in sample 1, an effect that disappears with the introduction of the mediating variables (Model 1).

$* * * * * * * * * * * * * * * * * * * * * * * * * * * * *$

Insert Table 4 about here

******************************* 
Our model predicted that perceived quality would be positively related to brand experience $(\mathrm{b} 1=0.197, \mathrm{p}<0.01 ; \mathrm{b} 2=0.255, \mathrm{p}<0.01)$, brand personality $(\mathrm{H} 6)(\mathrm{b} 1=0.226, \mathrm{p}<0.01 ; \mathrm{b} 2=0.372$, $\mathrm{p}<0.01)$, and perceived value $(\mathrm{H} 7)(\mathrm{b} 1=0.315, \mathrm{p}<0.01 ; \mathrm{b} 2=0.643, \mathrm{p}<0.01)$, and these were supported. Our investigation also demonstrates that brand experience is positively related to brand personality $(\mathrm{H} 8)(\mathrm{b} 1=0.354, \mathrm{p}<0.01 ; \mathrm{b} 2=0.189, \mathrm{p}<0.01)$ and perceived value $(\mathrm{H} 9)$ $(\mathrm{b} 1=0.104, \mathrm{p}<0.05 ; \mathrm{b} 2=0.138, \mathrm{p}<0.05)$. Finally, in both samples we observed that brand personality relates positively with perceived value $(\mathrm{H} 10)(\mathrm{b} 1=0.224, \mathrm{p}<0.01 ; \mathrm{b} 2=0.279$, $\mathrm{p}<0.05)$.

We also tested the existence of significant indirect effects (Table 5). For this, we relied on bootstrapping (Cheong \& MacKinnon, 2012). Brand innovativeness has a significant positive indirect and total effect on brand experience, brand personality and perceived value in both samples. Hence, we observe that the effects of innovativeness are partially mediated across samples, except in the case of perceived value in sample 1, where its effects are totally mediated. As to perceived quality, its indirect and total effects on brand personality and perceived value are significant and positive, which, given the significance of its direct effects, implies partial mediation. We also observe that brand experience has a significant positive total and indirect effect on perceived value, implying that its effects are partially mediated. As AMOS only provides overall tests of mediation, we also tested individual mediation effects using the Sobel test. These mediation effects are all positive and significant, the exception being the link perceived quality - brand experience - perceived value, which is not significant (we omitted a table with these results for parsimony reasons).

$* * * * * * * * * * * * * * * * * * * * * * * * * * * * *$

Insert Table 5 about here

******************************* 
Finally, we note that as a further check on CMV, we have added the marker variable to our Model 1, with paths to all dependent variables, and observed that all structural paths remained significant, which suggests that the results are robust to CMV (Siemsen, Roth, \& Oliveira, 2010).

\section{Discussion}

Managing brand experience and brand personality are two issues that have emerged as key for brand success (e.g., Brakus et al., 2009). Accordingly, it is of paramount importance to understand how firms can engender the characteristics of their offer in order to build brands that are perceived by consumers as generating a valued brand experience and personality. In this context, this study innovated by proposing that two functional product characteristics could be used to obtain such valued brand outcomes. Firms' investments in quality and innovation have grown substantially, but how they materialize in benefits for customers and in performance for companies remains widely uncovered (Molina-Castillo \& MunueraAleman, 2009). Hence, the results obtained in this study shed light on how such brand functional qualities turn into customer and firm value, namely through their effects on symbolic brand features, brand experience and brand personality.

The results support a chain of effects initiating with two functional variables, quality and innovativeness, whose effects are conveyed to brand experience and brand personality, which ultimately results in perceived value. The positive relationship between innovativeness and quality is important. Quality is associated with the extent to which a firm excels at meeting customer needs. It is therefore not surprising that it is a major driver of customer satisfaction (e.g., Chan, Yim, \& Lam, 2010). Hence, the results suggest that firms can stimulate consumers' perceptions of the degree of excellence of their brands by innovating, namely by introducing novel features and improving existing ones. Innovativeness also has an influence 
on brand experience and brand personality, supporting the idea that a brand that surprises markets with novelties, ends up providing emotional and symbolic benefits to customers. However, the direct relationship with perceived value is not significant in the first sample and negative in the second sample. It is possible that innovation comes at a higher price, thus reducing individual perceptions of value. Another explanation is that sometimes innovative features may be perceived as useless by consumers. Notwithstanding, the total effect of innovativeness on perceived value is positive in both cases, due to the indirect effect through brand experience and personality. This indicates that innovativeness contributes to consumers' perceptions of perceived value as long as it contributes to a brand's experience and personality. The results also indicate that the paths from innovativeness to brand quality, experience and brand personality are stronger in the American sample. Cultural differences might account for this. Compared to Portugal, the United States has a much lower score on the uncertainty avoidance cultural dimension of Hofstede (2019), and this suggests that American consumers might look at innovation in a more positive way.

Perceived quality is a key driver of the strength of a brand and of the relationship consumers maintain with a brand (e.g., Batra et al., 2012). The results support the proposed hypotheses, namely that quality relates positively to brand experience, brand personality and perceived value. These results back the idea that the consumption of products with a symbolic, hedonic, and aesthetic nature also draw on functional features, namely quality, which is a key driver of satisfaction, value, and loyalty (Netemeyer et al., 2004). Moreover, the results show that brand quality, apart from the direct effect, also has an indirect positive effect on perceived value through brand experience and personality. This implies that symbolic qualities help channel the benefits from functional qualities such as quality into brand value. Somewhat surprisingly, the mediating effect of brand experience on the relationship between perceived quality and perceived value was not statistically significant. This is possibly due to the weaker 
relationship between brand experience and perceived value. A possible explanation for this is that the price component of perceived value may not fit well with the greater elaboration of brands delivering an augmented experience. Moreover, the experiential component of consumption operates more at a subconscious level of cognitive processes (Hirschman \& Holbrook, 1982). These issues could make it more difficult to obtain a strong relationship between brand experience and perceived value. The results further indicate that brand experience has a positive influence on brand personality and on perceived value. Brand experience appears to have several different brand-related associations originating from its sensory and intellectual stimulations (Brakus et al., 2009), and our results reinforce this view. The results further show that brand personality has a positive impact on perceived value. Brand personality evokes a sense of identification, which appears to increase customer value, and therefore, the levels of consumer preference and usage (Rojas-Méndez et al., 2013).

The estimations of Model 1 to Model 4 support the conclusion that consideration of both functional and symbolic qualities contributes to the explanatory power over perceived value, and this conforms to Holbrook \& Hirschman's (1982) contention that the information processing model and the experiential consumption perspective complement each other. Our model and results further suggest that functional and symbolic qualities are interrelated, with the former contributing to the development of the experiential nature of consumption. Also noteworthy is that, across samples (see models Model 5 and 6), brand innovativeness appears to have a stronger effect on brand personality and on brand experience than perceived quality. Brand quality is a key ingredient for brand equity, but may lack sensitivity to market dynamics (Aaker, 1996), and this may explain its lower role in affecting our symbolic brand qualities. These results underscore the role that innovation plays at building the uniqueness of a brand (Fang, 2008), its superiority (Calantone et al., 2006), and customer surprise (Menguc et al., 2014). 
Overall, the results show that most of the proposed relationships hold across the two samples. This is noteworthy, given the markedly different characteristics of these samples, namely in terms of cultural background, age and income. This is particularly reassuring about the generalizability of the findings. In addition, in the student sample, respondents were free to select the brand and type of product, whereas in the second sample respondents were requested to focus on a specific product type, cellphones. Hence, the similarity of results across the two samples is also a sign of the generalizability of findings across products. Notwithstanding, it is possible that for specific products and purchase situations results may differ. Past studies indicate that consumers differentiate information collection and processing for high- and low-involvement products (e.g., Petty, Cacioppo, \& Schumann, 1983) and, in particular, that involvement influences the type of appeal (rational or emotional) that consumers value (e.g., Holmes \& Crocker, 1987). This suggests that the linkages from innovativeness and quality to perceived value through brand experience and brand personality may differ across product involvement levels. Relatedly, consumers may approach consumption with a utilitarian, cognitive information-seeking approach or with a "sensoryemotive stimulation seeking" one (Hirschman \& Holbrook, 1982, p. 95), and this could also affect the linkages in our model.

In summary, this research makes two major contributions. Firstly, it enlightened the role of functional brand features, namely quality and innovativeness, in explaining two symbolic brand qualities, brand experience and brand personality. Secondly, this investigation tested whether brand experience and brand personality helped in carrying out the effects of innovativeness and quality on perceived value, which is a valuable outcome of brand marketing efforts (La et al., 2009). In investigating the antecedents of brand experience and brand personality, past research has looked in particular at intangible qualities, underestimating the role of functional features, and we have contributed to overcome this. 
These results enlighten the chain of effects from functional features and perceived value, mediated by symbolic qualities.

\section{Managerial Implications}

Increasing quality and innovation means higher investments and costs, but firms and brand strategists must deal with limited budgets (Su \& Tong, 2015). Therefore, understanding how such investments and costs translate into firm benefits is important for prioritizing managerial intervention. The results suggest that quality contributes to perceived brand value directly and indirectly, and that innovativeness also contributes positively to the latter, though only indirectly. Moreover, the results indicate that quality and innovativeness help shape consumers' perceptions of symbolic brand attributes, namely brand personality and experience. Hence, these results serve to ensure managers that investing in quality and innovativeness pays off in terms of several outcomes at the consumer level, which will ultimately benefit the firm. Specifically, firms may enhance brand experience and personality by innovating in the aesthetics of the brand (including new colors and shapes), by relying on new materials, and by introducing novel product functions. Improvements in quality, which should also impact upon brand experience and personality, can be achieved through superior raw materials and components, improved product reliability and control quality systems, a higher integration between manufacturing and marketing, and insights about consumers' needs that are reverted into improved product performance. The bank Santander is opening new offices with a novel design, incorporating air conditioning systems, intelligent lighting, as well as visual and auditory systems to improve the experience of their customers (Iglesias et al., 2019). The choice of colours appears to contribute to the view of Apple as exciting, just like car design appears to help Peugeot and Porsche to be perceived as exciting (Maehle et al., 
2011). Hence, by carefully orchestrating the quality and innovativeness of their offers, brand managers can influence how their brand is experienced and perceived by consumers.

Accordingly, brand managers should set guidelines for quality and innovation, considering that these have far-reaching effects beyond consumer functional/technical assessments, and leveraging symbolic qualities, which will help in crafting unique brand experiences and a brand endowed with an identifiable, strong, and valuable personality. The negative direct relationship between brand innovativeness and perceived value (in sample 2) suggests that managers should also pay attention to the usefulness of innovative features. Specifically, the results denote that some innovation may be regarded by consumers as expensive and not useful, and managers must deal with this.

\section{Limitations and Directions for Future Research}

This investigation made an original contribution to existing knowledge, shedding light on the role of functional qualities in shaping brand symbolic attributes and customers' perceived value. Moreover, the results provided relevant managerial hints on how to improve brand experience and build brand personality, which ultimately generate value for customers. However, these contributions must be weighed against the limitations of the study. The results are based on cross sectional data, which fail to capture the chain of effects from utilitarian to hedonic and symbolic benefits depicted in the proposed model. Hence, longitudinal studies would add considerable insights in this debate. Moreover, the use of qualitative methods may provide additional clues on how consumers elaborate on functional attributes to attribute symbolic qualities to brands. The data also comes from a single source, which provided a selfreport on the dependent and independent variables, raising the issue of common method bias. Notwithstanding, and in line with Podsakoff et al. (2003), we adopted a number of procedural remedies that should have minimized the magnitude of such bias. Moreover, we ran a number 
of statistical procedures, which suggested that common method variance is not a major concern.

Our research model was supported with data from two markedly different samples, which is indicative of the generalizability of the results. Notwithstanding, conducting the study in different cultures might have important payoffs, as the obtained results denoted some differences between the two samples, which are characterized by different cultural backgrounds. In this research we also focused our attention on two key functional attributes, quality and innovation. It is likely that other functional elements also play a role in the development of brand symbolic qualities, and these deserve to be investigated. Finally, we obtained evidence that the findings are generalizable across product types. Notwithstanding, it is worthwhile investigating whether the factors shaping symbolic qualities vary across product types. 


\section{References}

Aaker, D. A. (1996). Measuring brand equity across products and markets. California Management Review, 38(3), 102-120. doi:10.2307/41165845

Aaker, J. L. (1997). Dimensions of Brand Personality. Journal of Marketing Research, 34(3), 347-356. doi:10.1177/002224379703400304

Aggarwal, P., \& McGill, A. L. (2011). When brands seem human, do humans act like brands? Automatic behavioral priming effects of brand anthropomorphism. Journal of Consumer Research, 39(2), 307-323. doi: https://doi.org/10.1086/662614

Ahuvia, A. C. (2005). Beyond the extended self: Loved objects and consumers' identity narratives. Journal of Consumer Research, 32(1), 171-184. doi:10.1086/429607

Alexandrov, A., Lilly, B., \& Babakus, E. (2013). The effects of social- and self-motives on the intentions to share positive and negative word of mouth. Journal of Academy of Marketing Science, 41(5), 531-546. doi:10.1007/s11747-012-0323-4

Andreini, D., Pedeliento, G., Zarantonello, L., \& Solerio, C. (2018). A renaissance of brand experience: Advancing the concept through a multi-perspective analysis. Journal of Business Research, 91, 123-133. doi: https://doi.org/10.1016/j.jbusres.2018.05.046

Ang, S. H., \& Lim, E. A. C. (2006). The influence of metaphors and product type on brand personality perceptions and attitudes. Journal of Advertising, 35(2), 39-53. doi:10.1080/00913367.2006.10639226

Bagozzi, R. P. (1983). Issues in the application of covariance structure analysis: A further comment. Journal of Consumer Research, 9(4), 449-450. doi: https://doi.org/10.1086/208939

Bao, J. Y. E., \& Sweeney, J. C. (2009). Comparing factor analytical and circumplex models of brand personality in brand positioning. Psychology \& Marketing, 26(10), 927-949. doi:10.1002/mar.20306

Batra, R., Ahuvia, A., \& Bagozzi, R. P. (2012). Brand Love. Journal of Marketing, 76(2), 116. doi:10.1509/jm.09.0339

Brakus, J. J., Schmitt, B. H., \& Zarantonello, L. (2009). Brand experience: What is it? How is it measured? Does it affect loyalty? Journal of Marketing, 73(3), 52-68. doi:10.1509/jmkg.73.3.52

Byrne, B. M. (2008). Testing for multigroup equivalence of a measuring instrument: A walk through the process. Psicothema, 20(4), 872-882.

Byrne, B. M., Shavelson, R. J., \& Muthén, B. (1989). Testing for the equivalence of factor 
covariance and mean structures: the issue of partial measurement invariance. Psychological Bulletin, 105(3), 456. doi: https://doi.org/10.1037/0033-2909.105.3.456

Calantone, R. J., Chan, K., \& Cui, A. S. (2006). Decomposing product innovativeness and its effects on new product success. Journal of Product Innovation Management, 23(5), 408-421. doi:10.1111/j.1540-5885.2006.00213.x

Carroll, B. A., \& Ahuvia, A. C. (2006). Some antecedents and outcomes of brand love. Marketing Letters, 17(2), 79-89. Doi:https://doi.org/10.1007/s11002-006-4219-2

Chan, K.W., Yim, C.K., \& Lam, S.S. (2010). Is customer participation in value creation a double-edged sword? Evidence from professional financial services across cultures. Journal of Marketing, 74(3), 48-64. doi:10.1509/jmkg.74.3.48

Chen, R. P., Wan, E. W., \& Levy, E. (2017). The effect of social exclusion on consumer preference for anthropomorphized brands. Journal of Consumer Psychology, 27(1), 2334. doi: https://doi.org/10.1016/j.jcps.2016.05.004

Cheong, J. W. \& MacKinnon, D. (2012). Mediation/indirect effects in structural equation modeling. In Rick H. Hoyle (Ed.), Handbook of Structural Equation Modeling (417435). London: Guilford Press.

Cheung, G. W., \& Rensvold, R. B. (2002). Evaluating goodness-of-fit indexes for testing measurement invariance. Structural Equation Modeling, 9(2), 233-255. doi: https://doi.org/10.1207/S15328007SEM0902_5

Chernev, A. (2004). Goal-attribute compatibility in consumer choice. Journal of Consumer Psychology, 14(1-2), 141-150. doi:10.1207/s15327663jcp1401\&2_16

Childers, T.L., Carr, C.L., Peck, J. and Carson, S. (2001). Hedonic and utilitarian motivations for online retail shopping behavior. Journal of Retailing, 77 (4), 511-535. doi:10.1016/s0022-4359(01)00056-2

Choi, W. J., \& Winterich, K. P. (2013). Can brands move in from the outside? How moral identity enhances out-group brand attitudes. Journal of Marketing, 77(1), 96-111. doi:10.1509/jm.11.0544

Cronin, J. J., Brady, M. K., \& Hult, G. T. M. (2000). Assessing the effects of quality, value, and customer satisfaction on consumer behavioral intentions in service environments. Journal of Retailing, 76(2), 193-218. doi:10.1016/s0022-4359(00)00028-2

Dhar, R., \& Wertenbroch, K. (2000). Consumer choice between hedonic and utilitarian goods. Journal of marketing research,37(1), 60-71. doi: https://doi.org/10.1509/jmkr.37.1.60.18718 
Dodds, W. B., Monroe, K. B., \& Grewal, D. (1991). Effects of price, brand, and store information on buyers' product evaluations. Journal of Marketing Research, 28(3), 307319. doi:10.1177/002224379102800305

Eisend, M., \& Stokburger-Sauer, N. E. (2013). Brand personality: A meta-analytic review of antecedents and consequences. Marketing Letters, 24(3), 205-216. doi:10.1007/s11002013-9232-7

Evanschitzky, H., \& Armstrong, J. S. (2013). Research with in-built replications: Comment and further suggestions for replication research. Journal of Business Research, 66(9), 1406-1408. doi: https://doi.org/10.1016/j.jbusres.2012.05.006

Fang, E. (2008). Customer participation and the trade-off between new product innovativeness and speed to market. Journal of Marketing, 72(4), 90-104. doi:10.1509/jmkg.72.4.90

Fornell, C. (1983). Issues in the application of covariance structure analysis: A comment. Journal of Consumer Research, 9(4), 443-448. doi:https://doi.org/10.1086/208938

Fornell, C., Johnson, M. D., Anderson, E. W., Cha, J., \& Bryant, B. E. (1996). The American Customer Satisfaction Index: Nature, purpose, and findings. Journal of Marketing, 60(4), 7-18. doi:10.1177/002224299606000403

Fornell, C., \& Larcker, D. F. (1981). Evaluating structural equation models with unobservable variables and measurement error. Journal of Marketing Research, 18(1), 39-50. doi:10.1177/002224378101800104

Fournier, S. (1998). Consumers and their Brands: Developing relationship theory in consumer research. Journal of Consumer Research, 24(4), 343-373. doi:10.1086/209515

Fournier, S. \& Alvarez, Claudio (2012). Brands as relationship partners: Warmth, competence, and in-between. Journal of Consumer Psychology, 22, 177-185. doi: https://doi.org/10.1016/j.jcps.2011.10.003

Gerbing, D. W., \& Anderson, J. C. (1984). On the meaning of within-factor correlated measurement errors. Journal of Consumer Research, 11(1), 572-580. doi: https://doi.org/10.1086/208993

Gilson, L. L., Mathieu, J. E., Shalley, C. E., \& Ruddy, T. M. (2005). Creativity and standardization: Complementary or conflicting drivers of team effectiveness? Academy of Management Journal, 48(3), 521-531. doi:10.5465/amj.2005.17407916

Golder, P. N., Mitra, D., \& Moorman, C. (2012). What is quality? An integrative framework of processes and states. Journal of Marketing, 76(4), 1-23. doi:10.1509/jm.09.0416 
Gourville, J. T. (2006). Eager sellers and stony buyers: Understanding the psychology of newproduct adoption. Harvard Business Review, 84(6), 99-106.

Han, J. K., Kim, N., \& Srivastava, R. K. (1998). Market orientation and organizational performance: Is innovation a missing link? Journal of Marketing, 62(4), 30-45. doi:10.1177/002224299806200403

Hirschman, E. C., \& Holbrook, M. B. (1982). Hedonic consumption: emerging concepts, methods and propositions. Journal of Marketing, 46(3), 92-101. doi: https://doi.org/10.1177/002224298204600314

Hofstede (2019), Retrieved February 8, 2019, from https://www.hofstedeinsights.com/product/compare-countries/

Holbrook, M. B., \& Hirschman, E. C. (1982). The experiential aspects of consumption: Consumer fantasies, feelings, and fun. Journal of Consumer Research, 9(2), 132-40. doi:10.1086/208906

Holmes, J. H., \& Crocker, K. E. (1987). Predispositions and the comparative effectiveness of rational, emotional and discrepant appeals for both high involvement and low involvement products. Journal of the Academy of Marketing Science, 15(1), 27-35. doi: https://doi.org/10.1007/BF02721951

Huang, C. C. (2017). The impacts of brand experiences on brand loyalty: mediators of brand love and trust. Management Decision, 55(5), 915-934. doi:10.1108/md-10-2015-0465

Huang, H. H., Mitchell, V. W., \& Rosenaum-Elliott, R. (2012). Are consumer and brand personalities the same? Psychology \& Marketing, 29(5), 334-349. doi:10.1002/mar.20525

Iglesias, O., Markovic, S., \& Rialp, J. (2019). How does sensory brand experience influence brand equity? Considering the roles of customer satisfaction, customer affective commitment, and employee empathy. Journal of Business Research, 96, 343-354. doi: https://doi.org/10.1016/j.jbusres.2018.05.043

Keller, K. L. (1993). Conceptualizing, measuring, and managing customer-based brand equity. Journal of Marketing, 57(7), 1-22. doi:10.1177/002224299305700101

Keller, K. L. (2003). Brand synthesis: The multidimensionality of brand knowledge. Journal of Consumer Research, 29(4), 595-600. doi:10.1086/346254

Keller, K. L., \& Lehmann, D. R. (2006). Brands and branding: Research findings and future priorities. Marketing Science, 25(6), 740-759. doi:10.1287/mksc.1050.0153 
Kim, D. H., \& Sung, Y. (2013). Gucci versus Old Navy: Interplay of brand personality and regulatory focus in advertising persuasion. Psychology \& Marketing, 30(12), 10761087. doi:10.1002/mar.20668

Klein, J. F., Falk, T., Esch, F. R., \& Gloukhovtsev, A. (2016). Linking pop-up brand stores to brand experience and word of mouth: The case of luxury retail. Journal of Business Research, 69(12), 5761-5767. doi:10.1016/j.jbusres.2016.04.172

Kotler, P. (2003) Marketing Management. 11th Edition, Prentice-Hall, Upper Saddle River.

Kunz, W., Schmitt, B., \& Meyer, A. (2011). How does perceived firm innovativeness affect the consumer? Journal of Business Research, 64(8), 816-822. doi:10.1016/j.jbusres.2010.10.005

La, V., Patterson, P., \& Styles, C. (2009). Client-perceived performance and value in professional B2B services: An international perspective. Journal of International Business Studies, 40(2), 274-300. doi:10.1057/palgrave.jibs.8400406

Lam, S. K., Ahearne, M., Mullins, R., Hayati, B., \& Schillewaert, N. (2013). Exploring the dynamics of antecedents to consumer-brand identification with a new brand. Journal of the Academy of Marketing Science, 41(2), 234-252. doi:10.1007/s11747-012-0301-x

Lau, K. C., \& Phau, I. (2007). Extending symbolic brands using their personality: Examining antecedents and implications towards brand image fit and brand dilution. Psychology \& Marketing, 24(5), 421-444. doi:10.1002/mar.20167

Levy, S. J. (1959). Symbols for sale. Harvard Business Review, 37(4), 117-124.

Lindell, M.K. \& Whitney, D.J. (2001), Accounting for common method variance in crosssectional research designs, Journal of Applied Psychology, 86(1), 114-121. doi:10.1037/0021-9010.86.1.114

Lin, Y. H. (2015). Innovative brand experience's influence on brand equity and brand satisfaction. Journal of Business Research, 68(11), 2254-2259. doi: 10.1016/j.jbusres.2015.06.007

Little, T. D. (1997). Mean and covariance structures (MACS) analyses of cross-cultural data: Practical and theoretical issues. Multivariate Behavioral Research, 32(1), 53-76. Doi: https://doi.org/10.1207/s15327906mbr3201_3

Long, J. (2002). Continuous learning: The creative journey from research to innovation and invention. Design Management Journal, 13(2), 20-23. doi:10.1111/j.19487169.2002.tb00304.X

Maehle, N., Otnes, C., \& Supphellen, M. (2011). Consumers' perceptions of the dimensions of brand personality. Journal of Consumer Behaviour, 10(5), 290-303. doi: 
$10.1002 / \mathrm{cb} .355$

Malär, L., Nyffenegger, B., Krohmer, H., \& Hoyer, W. D. (2012). Implementing an intended brand personality: A dyadic perspective. Journal of the Academy of Marketing Science, 40(5), 728-744. doi:10.1007/s11747-011-0251-8

Menguc, B., Auh, S., \& Yannopoulos, P. (2014). Customer and supplier involvement in design: The moderating role of incremental and radical innovation capability. Journal of Product Innovation Management, 31(2), 313-328. doi:10.1111/jpim.12097

Mishra, A. S., Roy, S., \& Bailey, A. A. (2015). Exploring brand personality-celebrity endorser personality congruence in celebrity endorsements in the Indian context. Psychology \& Marketing, 32(12), 1158-1174. doi:10.1002/mar.20846

Molina-Castillo, F. J., \& Munuera-Aleman, J. L. (2009). The joint impact of quality and innovativeness on short-term new product performance. Industrial Marketing Management, 38(8), 984-993. doi:10.1016/j.indmarman.2008.06.001

Moorman, C. (1995). Organizational market information processes: Cultural antecedents and new product outcomes. Journal of Marketing Research, 32(3), 318-335. doi: $10.2307 / 3151984$

Moultrie, J., Clarkson, P. J., \& Probert, D. (2007). Development of a design audit tool for SMEs. Journal of Product Innovation Management, 24(4), 335-368. doi:10.1111/j.1540-5885.2007.00255.x

Netemeyer, R. G., Krishnan, B., Pullig, C., Wang, G., Yagci, M., Dean, D., Ricks, Joe, \& Wirth, F. (2004). Developing and validating measures of facets of customer-based brand equity. Journal of Business Research, 57(2), 209-224. doi:https://doi.org/10.1016/S0148-2963(01)00303-4

Olshavsky, R. W., \& Granbois, D. H. (1979). Consumer decision making-fact or fiction? Journal of Consumer Research, 6(2), 93-100. doi:10.1086/208753

Peer, E., Vosgerau, J., \& Acquisti, A. (2014). Reputation as a sufficient condition for data quality on Amazon Mechanical Turk. Behavior research methods, 46(4), 1023-1031. doi:10.3758/s13428-013-0434-y

Petty, R. E., Cacioppo, J. T., \& Schumann, D. (1983). Central and peripheral routes to advertising effectiveness: The moderating role of involvement. Journal of Consumer Research, 10(2), 135-146. doi: https://doi.org/10.1086/208954

Podsakoff, P. M., MacKenzie, S. B., Lee, J.-Y., \& Podsakoff, N. P. (2003). Common method biases in behavioral research: a critical review of the literature and recommended remedies. The Journal of Applied Psychology, 88(5), 879-903. doi:10.1037/0021- 
9010.88.5.879

Puzakova, M., Kwak, H., \& Rocereto, J. F. (2009). Pushing the envelope of brand and personality: Antecedents and moderators of anthropomorphized brands. Advances in Consumer Research, 36, 413-420.

Puzakova, M., Kwak, H., \& Rocereto, J. F. (2013). When humanizing brands goes wrong: the detrimental effect of brand anthropomorphization amid product wrongdoings. Journal of Marketing, 77(3), 81-100. doi: https://doi.org/10.1509/jm.11.0510

Rauschnabel, P. A., Krey, N., Babin, B. J., \& Ivens, B. S. (2016). Brand management in higher education: the university brand personality scale. Journal of Business Research, 69(8), 3077-3086. doi:https://doi.org/10.1016/j.jbusres.2016.01.023

Rojas-Méndez, J. I., Murphy, S. A., \& Papadopoulos, N. (2013). The US brand personality: A Sino perspective. Journal of Business Research, 66(8), 1028-1034. doi:10.1016/j.jbusres.2011.12.027

Rosenberg, M. (1979). Conceiving the self. New York: Basic Books.

Rust, R. T., Moorman, C., \& Dickson, P. T. (2002). Getting return on quality: Revenue expansion, cost reduction, or both? Journal of Marketing, 66(4), 7-24. doi:10.1509/jmkg.66.4.7.18515

Schembri, S. (2009). Reframing brand experience: The experiential meaning of HarleyDavidson. Journal of Business Research, 62(12), 1299-1310. doi:10.1016/j.jbusres.2008.11.004

Siemsen, E., Roth, A., \& Oliveira, P. (2010). Common method bias in regression models with linear, quadratic, and interaction effects. Organizational Research Methods, 133, 456476. doi:10.1177/1094428109351241

Sirgy, M. J. (1982). Self-concept in consumer behavior: A critical review. Journal of Consumer Research, 9(3), 287-300. doi: https://doi.org/10.1086/208924

Sirohi, N., McLaughlin, E., \& Wittink, D. (1998). A model of consumer perceptions and store loyalty intentions for a supermarket retailer. Journal of Retailing, 74(2), 223-245. doi:10.1016/s0022-4359(99)80094-3

Steenkamp, J. B. E., \& Baumgartner, H. (1998). Assessing measurement invariance in crossnational consumer research. Journal of Consumer Research, 25(1), 78-90. doi: https://doi.org/10.1086/209528

Su, J., \& Tong, X. (2015). Brand personality and brand equity: Evidence from the sportswear industry. Journal of Product \& Brand Management, 24(2), 124-133. doi:10.1108/jpbm01-2014-0482 
Sung, Y., \& Kim, J. (2010). Effects of brand personality on brand trust and brand affect. Psychology \& Marketing, 27(7), 639-661. doi:10.1002/mar.20349

Sung, Y., Choi, S. M., Ahn, H., \& Song, Y. A. (2015). Dimensions of luxury brand personality: Scale development and validation. Psychology \& Marketing, 32(1), 121 132. doi:10.1002/mar.20767

Swaminathan, V., Stilley, K. M., \& Ahluwalia, R. (2008). When brand personality matters: The moderating role of attachment styles. Journal of Consumer Research, 35(6), 9851002. doi:10.1086/593948

Tuskej, U., Golob, U., \& Podnar, K. (2013). The role of consumer-brand identification in building brand relationships. Journal of Business Research, 66(1), 53-59. doi:10.1016/j.jbusres.2011.07.022

Uncles, M. D., \& Kwok, S. (2013). Designing research with in-built differentiated replication. Journal of Business Research, 66(9), 1398-1405. doi:https://doi.org/10.1016/j.jbusres.2012.05.005

Venable, B. T., Rose, G. M., Bush, V. D., \& Gilbert, F. W. (2005). The role of brand personality in charitable giving: An assessment and validation. Journal of the Academy of Marketing Science, 33(3), 295-312. doi:10.1177/0092070305276147

Valette-Florence, P., Guizani, H., \& Merunka, D. (2011). The impact of brand personality and sales promotions on brand equity. Journal of Business Research, 64(1), 24-28. doi:10.1016/j.jbusres.2009.09.015

Veryzer, R. W., \& Mozota, B. B. (2005). The impact of user-oriented design on new product development: An examination of fundamental relationships. Journal of Product Innovation Management, 22(2), 128-143. doi:10.1111/j.0737-6782.2005.00110.x

Zanjani, S. H., Milne, G. R., \& Miller, E. G. (2016). Procrastinators' online experience and purchase behavior. Journal of the Academy of Marketing Science, 44(5), 568-585. doi: http://dx.doi.org/10.1007/s11747-015-0458-1

Zarantonello, L., \& Schmitt, B. H. (2013). The impact of event marketing on brand equity: The mediating roles of brand experience and brand attitude. International Journal of Advertising, 32(2), 255-280. doi:10.2501/ija-32-2-255-280

Zeithaml, V. (1988). Consumer perceptions of price, quality, and value: A means-end model and synthesis of evidence. Journal of Management Studies, 52(3), 2-22. doi:10.1177/002224298805200302 


\section{Table 1 - Definition of constructs}

\begin{tabular}{|c|c|}
\hline \multicolumn{2}{|l|}{ Brand personality } \\
\hline $\begin{array}{l}\text { Brand personality is the "the set of human characteristics } \\
\text { associated with a brand" }\end{array}$ & Aaker (1997, p. 347) \\
\hline \multicolumn{2}{|l|}{ Brand experience } \\
\hline $\begin{array}{l}\text { Brand experience is conceptualized "as subjective, } \\
\text { internal consumer responses (sensations, feelings, and } \\
\text { cognitions), and behavioral responses evoked by brand- } \\
\text { related stimuli that are part of a brand's design and } \\
\text { identity, packaging, communications, and environments" }\end{array}$ & $\begin{array}{l}\text { Brakus et al. (2009, } \\
\text { p. 53) }\end{array}$ \\
\hline \multicolumn{2}{|l|}{ Brand innovativeness } \\
\hline $\begin{array}{l}\text { Brand innovativeness is defined as "consumer's } \\
\text { perception of an enduring firm capability that results in } \\
\text { novel, creative, and impactful ideas and solutions for the } \\
\text { market" }\end{array}$ & $\begin{array}{l}\text { Kunz et al. (2011, p. } \\
\text { 817) }\end{array}$ \\
\hline \multicolumn{2}{|l|}{ Perceived quality } \\
\hline $\begin{array}{l}\text { "Perceived quality can be defined as the consumer's } \\
\text { judgment about a product's overall excellence or } \\
\text { superiority" }\end{array}$ & $\begin{array}{l}\text { Zeithaml (1988, p. } \\
\text { 3) }\end{array}$ \\
\hline \multicolumn{2}{|l|}{ Perceived value } \\
\hline $\begin{array}{l}\text { "Perceived value is the consumer's overall assessment of } \\
\text { the utility of a product based on perceptions of what is } \\
\text { received and what is given" }\end{array}$ & $\begin{array}{l}\text { Zeithaml (1988, p. } \\
\text { 14) }\end{array}$ \\
\hline
\end{tabular}


Table 2 - Results of Confirmatory Factor Analysis

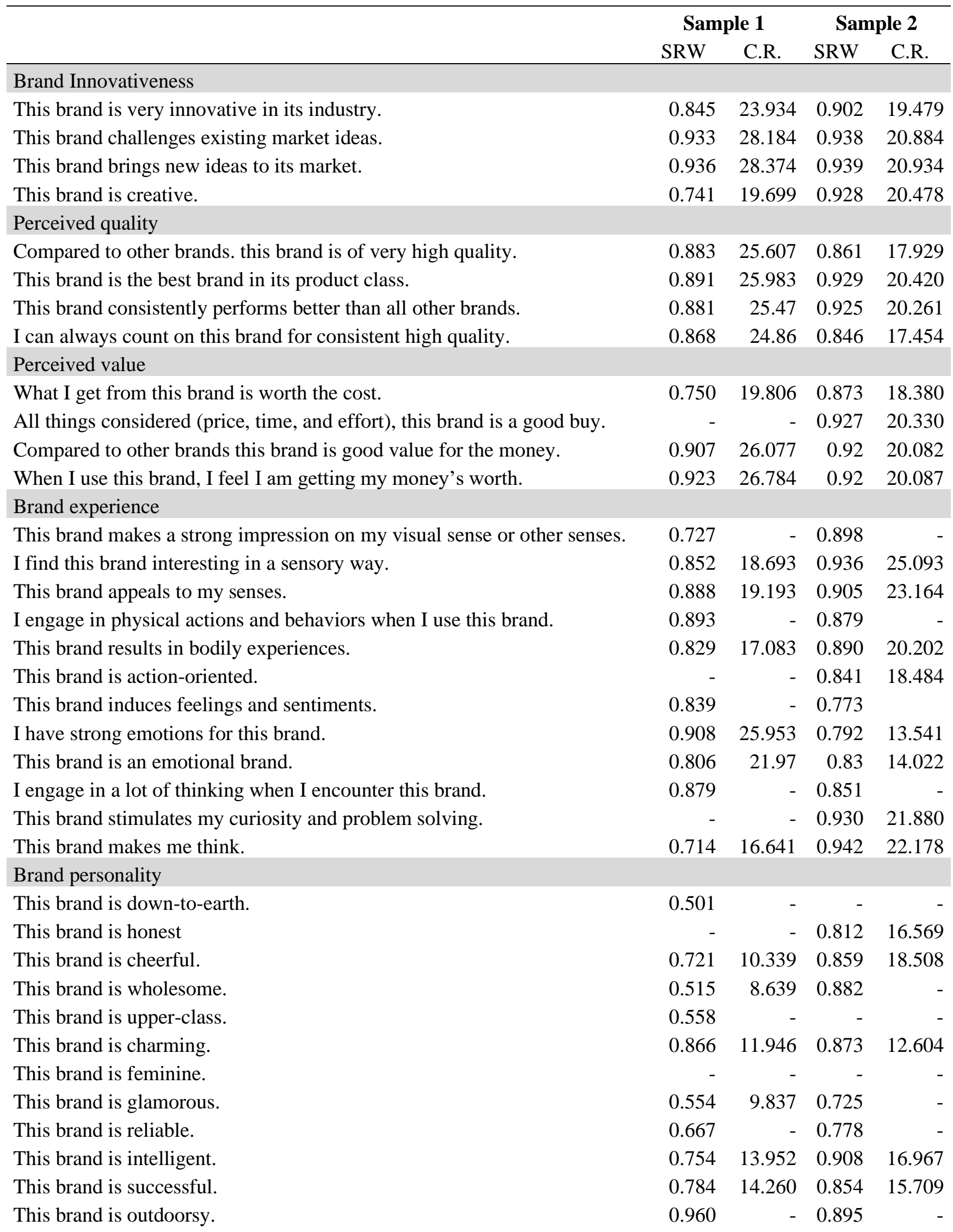


This brand is tough.

\begin{tabular}{rrrr}
0.422 & 7.680 & 0.879 & 20.030 \\
- & - & 0.881 & 20.370 \\
0.292 & 5.852 & 0.63 & 12.048 \\
0.719 & - & - & - \\
0.827 & 17.938 & - & - \\
0.841 & 18.195 & 0.878 & 18.723 \\
0.686 & 14.974 & 0.838 & - \\
\hline
\end{tabular}

This brand is rugged.

This brand is masculine.

This brand is daring.

This brand is spirited.

This brand is imaginative.

$\begin{array}{lll}0.686 & 14.974 & 0.838\end{array}$

This brand is up-to-date. 
Table 3 - Standard Deviations, Correlations, Cronbach Alphas, Composite Reliabilities, and Average Variances Extracted

\begin{tabular}{lllllllll}
\hline & SD & X1 & X2 & X3 & X4 & X5 & CR & AVE \\
\hline Sample 1 & & & & & & & & \\
Brand innovativeness (X1) & 1.400 & $\mathbf{0 . 9 1 9}$ & & & & & 0.923 & 0.752 \\
Perceived quality (X2) & 1.160 & 0.565 & $\mathbf{0 . 9 3 2}$ & & & & 0.933 & 0.776 \\
Perceived value (X3) & 0.989 & 0.336 & 0.463 & $\mathbf{0 . 8 9 1}$ & & & 0.897 & 0.746 \\
Brand experience (X4) & 0.832 & 0.496 & 0.414 & 0.354 & $\mathbf{0 . 9 0 6}$ & & 0.886 & 0.663 \\
Brand personality (X5) & 0.562 & 0.585 & 0.532 & 0.438 & 0.588 & $\mathbf{0 . 8 7 1}$ & 0.914 & 0.683 \\
Sample 2 & & & & & & & & \\
Brand innovativeness (X1) & 1,270 & $\mathbf{0 . 9 6 0}$ & & & & & 0.859 & 0.961 \\
Perceived quality (X2) & 1,225 & 0.822 & $\mathbf{0 . 9 3 7}$ & & & & 0.794 & 0.939 \\
Perceived value (X3) & 1,126 & 0.427 & 0.609 & $\mathbf{0 . 9 5 1}$ & & & 0.829 & 0.951 \\
Brand experience (X4) & 1,037 & 0.628 & 0.599 & 0.445 & $\mathbf{0 . 9 4 8}$ & & 0.754 & 0.924 \\
Brand personality (X5) & 1,042 & 0.839 & 0.826 & 0.548 & 0.673 & $\mathbf{0 . 9 3 8}$ & 0.665 & 0.901 \\
\hline Note Dign
\end{tabular}

Notes: Diagonal entries are Cronbach's alpha coefficients; $\mathrm{CR}=$ Composite Reliability; AVE $=$ Average

Variance Extracted; $\mathrm{SD}=$ Standard Deviations. 


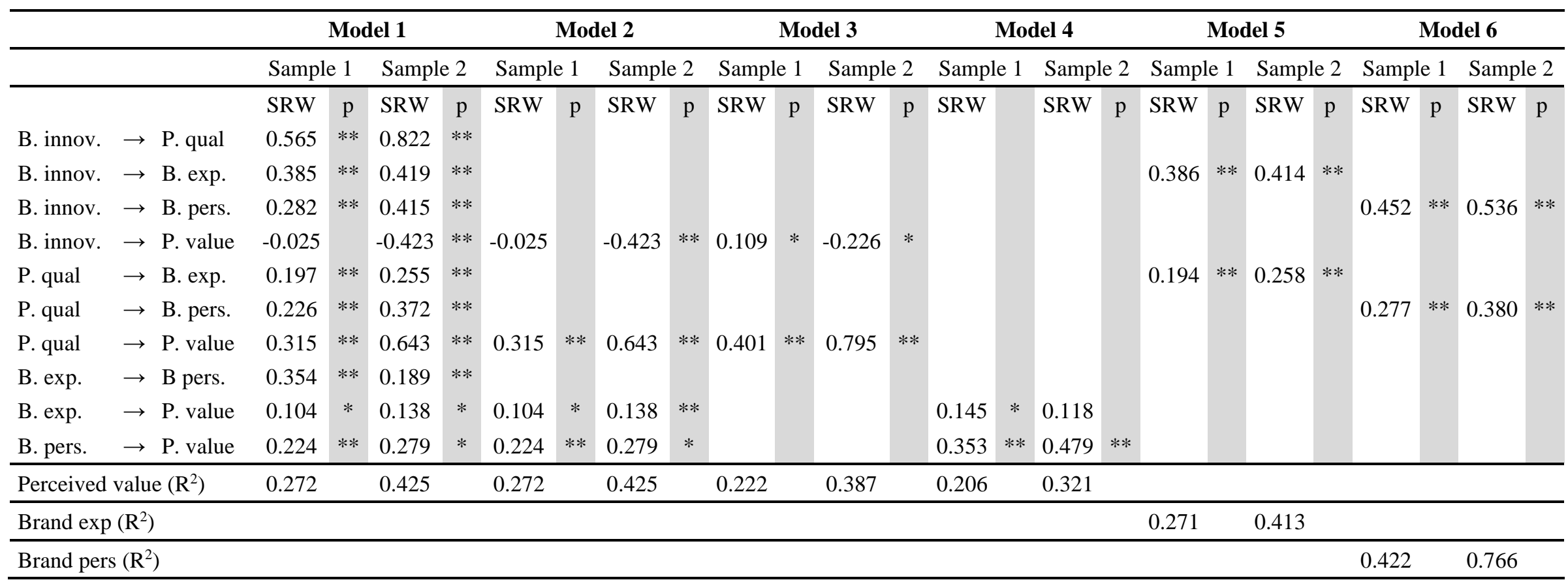

Notes:

$* *<0.01 ; *<0.05$ (one-tailed test)

Model 1- sample 1: $\chi 2=1768.89 ; \mathrm{df}=610 ; \mathrm{IFI}=0.91 ; \mathrm{TLI}=0.90 ; \mathrm{CFI}=0.91 ; \mathrm{RMSEA}=0.06 ; \chi 2 / \mathrm{df}=2.90 \mid$ sample $2: \chi 2=1712.69 ; \mathrm{df}=647 ; \mathrm{IFI}=0.91 ; \mathrm{TLI}=0.90 ; \mathrm{CFI}=0.90 ;$ RMSEA $=0.08 ; \chi 2 / \mathrm{df}=2.65$

Model 2- sample $1: \chi 2=1768.89 ; \mathrm{df}=610 ; \mathrm{IFI}=0.91 ; \mathrm{TLI}=0.90 ; \mathrm{CFI}=0.91 ; \mathrm{RMSEA}=0.06 ; \chi 2 / \mathrm{df}=2.90 \mid$ sample $2: \chi 2=1712.69 ; \mathrm{df}=647 ; \mathrm{IFI}=0.91 ; \mathrm{TLI}=0.90 ; \mathrm{CFI}=0.90 ;$ RMSEA $=0.08 ; \chi 2 / \mathrm{df}=2.65$

Model 3- sample 1: $\chi 2=147.94: \mathrm{df}=41 ; \mathrm{IFI}=0.98 ; \mathrm{TLI}=0.97 ; \mathrm{CFI}=0.98 ; \mathrm{RMSEA}=0.07 ; \chi 2 / \mathrm{df}=3.61 \mid$ sample $2: \chi 2=116.00 ; \mathrm{df}=51 ; \mathrm{IFI}=0.98 ; \mathrm{TLI}=0.98 ; \mathrm{CFI}=0.98 ;$ $\mathrm{RMSEA}=0.07 ; \chi 2 / \mathrm{df}=2.27$

Model 4- sample 1: $\chi 2=1122.18 ; \mathrm{df}=365 ; \mathrm{IFI}=0.91 ; \mathrm{TLI}=0.90 ; \mathrm{CFI}=0.91 ; \mathrm{RMSEA}=0.07 ; \chi 2 / \mathrm{df}=3.07 \mid$ sample $2: \chi 2=1138.66 ; \mathrm{df}=394 ; \mathrm{IFI}=0.91 ; \mathrm{TLI}=0.90 ; \mathrm{CFI}=0.91$; RMSEA $=0.08 ; \chi 2 / \mathrm{df}=2.90$

Model 5- sample 1: $\chi 2=322.694 ; \mathrm{df}=128 ; \mathrm{IFI}=0.97 ; \mathrm{TLI}=0.97 ; \mathrm{CFI}=0.97 ; \mathrm{RMSEA}=0.06 ; \chi 2 / \mathrm{df}=2.60 \mid$ sample $2: \chi 2=709.92 ; \mathrm{df}=181 ; \mathrm{IFI}=0.92 ; \mathrm{TLI}=0.91 ; \mathrm{CFI}=0.92 ;$ RMSEA $=0.07 ; \chi 2 / \mathrm{df}=3.92$

Model 6- sample 1: $\chi 2=372.59 ; \mathrm{df}=163 ; \mathrm{IFI}=0.97 ; \mathrm{TLI}=0.96 ; \mathrm{CFI}=0.97 ; \mathrm{RMSEA}=0.07 ; \chi 2 / \mathrm{df}=2.29 \mid$ sample $2: \chi 2=534.095 ; \mathrm{df}=145 ; \mathrm{IFI}=0.97 ; \mathrm{TLI}=0.91 ; \mathrm{CFI}=0.93$; $\mathrm{RMSEA}=0.1 ; \chi 2 / \mathrm{df}=3.683$ 
Table 5 - Mediation Effects

\begin{tabular}{|c|c|c|c|c|c|c|c|c|c|}
\hline \multirow{2}{*}{ Sample 1} & \multicolumn{3}{|c|}{ Brand experience } & \multicolumn{3}{|c|}{ Brand personality } & \multicolumn{3}{|c|}{ Perceived value } \\
\hline & TE & DE & IE & TE & DE & IE & TE & DE & IE \\
\hline Brand Innovativeness & $0.496 * *$ & $0.385^{* *}$ & $0.111^{* *}$ & $0.585^{* *}$ & $0.282 * *$ & $0.303 * *$ & $0.336 * *$ & -0.025 & $0.360 * *$ \\
\hline Perceived quality & $0.197 * *$ & $0.197 * *$ & & $0.295^{* *}$ & $0.226^{* *}$ & $0.070 * *$ & $0.401 * *$ & $0.315^{* *}$ & $0.087 * *$ \\
\hline Brand experience & & & & $0.354 * *$ & $0.354 * *$ & & $0.183 * *$ & $0.104 *$ & $0.079 * *$ \\
\hline \multirow{2}{*}{ Sample 2} & \multicolumn{3}{|c|}{ Brand experience } & \multicolumn{3}{|c|}{ Brand personality } & \multicolumn{3}{|c|}{ Perceived value } \\
\hline & TE & DE & IE & $\mathbf{T E}$ & DE & IE & $\mathbf{T E}$ & DE & IE \\
\hline Brand Innovativeness & $0.628 * *$ & $0.419 * *$ & $0.210^{*}$ & $0.839 * *$ & $0.415^{* *}$ & $0.424 * *$ & $0.427 * *$ & $-0.423 * *$ & $0.849 * *$ \\
\hline Perceived quality & $0.255^{*}$ & $0.255^{*}$ & & $0.420 * *$ & $0.372 * *$ & $0.048 * *$ & $0.796 * *$ & $0.643 * *$ & $0.152 * *$ \\
\hline Brand experience & & & & $0.189 * *$ & $0.189 * *$ & & $0.190 * *$ & $0.138 *$ & $0.053^{*}$ \\
\hline
\end{tabular}

Notes: $(1) * *<0.01 ; *<0.05$ (one-tailed test); (2) TE= total effect; $\mathrm{DE}=$ direct effect; $\mathrm{IE}=$ indirect effect 